38. The Comparative Anatomy of the Tongues of the Mammalia.-V. Lemuroidea and Tarsioidea. By Charles F. Sonntag, M.D., F.Z.S., Anatomist to the Society.

[Received August 8, 1921 : Read November 8, 1921.]

$$
\text { (Text-figures 66-69.) }
$$

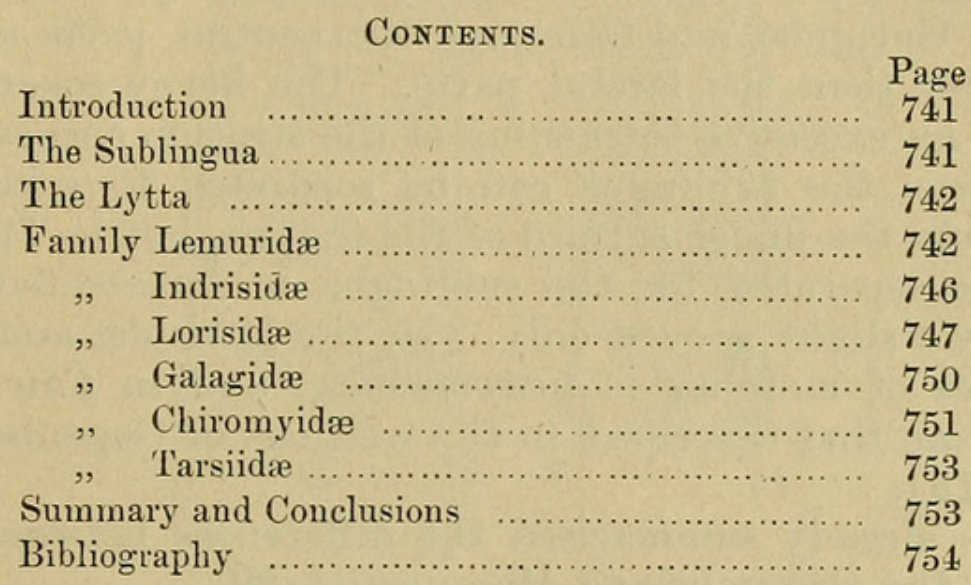

\title{
INTRODUCTION.
}

The literature of the tongues of the Lemuroidea and Tarsioidea is extensive, but it deals mainly with the organs of taste and the characters and significance of the sublingua. A few tongues have been described in detail in monographs on certain animals*, but little attention has been paid to some features which are of value for purposes of classification. The present paper is based on the examination of specimens in the Society's Prosectorium and the Museum of the Royal College of Surgeons, the latter being described as Mus. R.C.S.

In the Lemuroidea and Tarsioidea the foramen cæcum and apical gland of Nuhn are absent. Some have no lateral organs, and the lytta appears for the first time in the Primates. The frenal lamellæ are sometimes very complex.

\section{The Sublingua.}

The first description was contained in Tiedemann's paper on Stenops (18), but John Hunter had observed it previously and likened it to the tongue of a bird. It.is horny, devoid of taste buds, and fixed to the mandible by a frenum. Small muscle bundles derived from the hyoglossus and genioglossus run into it.

It is lyrate (Lemuridæ and Indrisidæ) or tongue-shaped (Lorisidæ and Galagidæ), and has a variable number of apical denticles which differ in character in different animals; these are absent in Tarsius and Chiromys, but the latter has a strong projection on the centre of its anterior border.

\footnotetext{
* See papers 2, 3, 6, 7, 13, 14, and 16 in Bibliography.
} 
Crests are present on the ventral surface in all species. They are three in number in the Indrisidæ and Lemuridæ, except Microcebus, but only one is present in the Lorisidæ, Galagidæ, Microcebus, Chiromys, and Tarsius. The dorsal surface bears a crest of variable size in the Lorisidæ and Galagidæ, the most pronounced one occurring in Perodicticus potto.

The consistence varies greatly. In all the Lemuroidea the sublingua is horny, but in Tarsius it is soft. In the Lemuridæ and Indrisidæe the entire sublingua is uniformly thick, but in the Lorisidæ, Galagidæ, and Chiromys the central parts are thicker and harder than the lateral parts. The horny covering is produced by an excessive thickening of the stratum corneum.

In Lemur the sublingua can be separated to a considerable extent from the under surface of the tongue, but in Tarsius they cannot be separated, for the sublingua is demarcated from the tongue by a slight groove only. In the Lorisidæ aud Galagidæ the degree of mobility is intermediate, and in Chiromys it is greater than that described in the writings of Gegenbaur (5) and Pocock (15).

I have already summarised the differences between the sublinguæ of the Prosimiæ and Marsupialia (20).

Flower (4) and Pocock (15) believe that the function of the sublingua is to clean the posterior surfaces of the incisor teeth; but others think it has no function, and regard it purely from the point of view of phylogeny. I believe that the sublingua of the Marsupialia is entirely a vestigial structure.

The Lytta.

The tongues of the Lemuroidea and Tarsioidea have lyttæ which are of two kinds:-1. The lytta of the tongue. 2. The lytta of the sublingua.

The lytta of the sublingua is absent in Lemur, double in Tarsius, and single in Perodicticus and Loris; in all these forms it is internal, but in Chiromys it forms a strong, external, nodulated ridge ending anteriorly in a hook.

The lytta of the tongue is present in Perodicticus, Loris, and Chiromys, but Gegenbaur and Owen missed it in the latter. It is connected to the lytta of the sublingua by connective tissue.

I have nothing to add to existing accounts of the histology of the sublingua and lytta.

\section{Family Le M UR ID E.}

\section{Genus Lemur.}

In all species the apex is rounded and covered with small conical and fungiform papillæ, but has no notch. The lateral borders increase in thickness from before backwards and have lateral organs at their posterior extremities. The oral part of the dorsum possesses several wide, shallow transverse ridges and sulci, and there is a smooth, non-papillary area in front of the 
epiglottis biserted by the median glosso-epiglottic fold. Small ridges may be present under the apex and send forward pointed processes (text-fig. $66 \mathrm{C}$ ).

Text-figure 66.
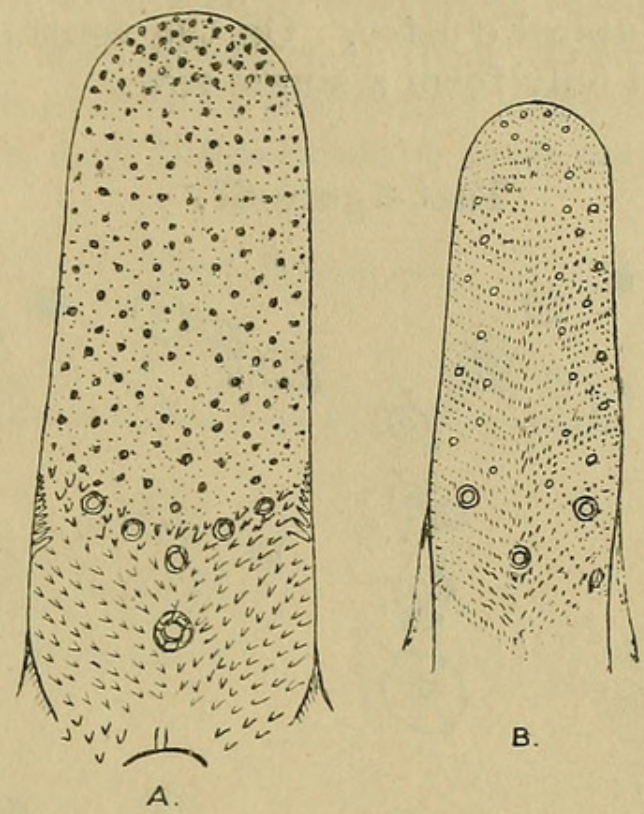

B.

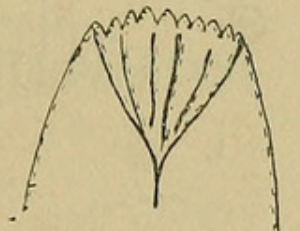

c.

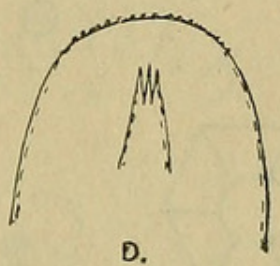

The tongues of Lemur catta (A) and Nycticebus tardigradus (B); C and D. the under surfaces of two examples of the tongue of Lemur rufifrons.

The circumvallate papillæ are arranged in $\mathbf{Y}$-formation in must species. They are round or oval, and are surrounded by an annular or lobulated vallum. They may be equal in size, or the most posterior papilla may be the largest. The following arrangements were seen by me or recorded by others:-

1. Lemur catta: Six papillæ in $\mathrm{Y}$-formation (text-fig. $66 \mathrm{~A}$ ).

2. L. fulvus: Nine papillæ in $\mathbf{Y}$-formation (text-fig. $67 \mathrm{~A}$ ).

3. L. fulvus rufifrons: Nine papillæ in $\mathrm{Y}$-formation (textfig. $67 \mathrm{E})$.

4. L. macaco : Eight papillæ in $\mathbf{Y}$-formation (text-fig. $67 \mathrm{~F}$ ).

5. L. varius: Five papillæ in $\mathrm{Y}$-formation.

6. L. mongoz: Nine papillæ in $\mathbf{Y}$-formation (text-fig. $67 \mathrm{I}$ ).

7. L. mongoz: Four papillæ forming a double pair.

8. L. melınocephalc: Nine papillıe in $\mathbf{Y}$-formation (Münch).

9. L. rubriventer : A pair of papillæ (Münch).

Proc. Zool. Soc.-1921, No. L. 
The papillæ may be concealed by the long conical papillæ on the base of the tongue (text-fig. $67 \mathrm{C}$ ), or there may be a clear zone between them (text-fig. $67 \mathrm{D})$.

The fungiform papillæ, which are small and numerous, stretch right across the dorsum, but have the usual arrangement in clusters and rows. The transverse ridges extend far forwards at the expense of the apical cluster. On the ventral papillary zone they are scanty and only form a single row.

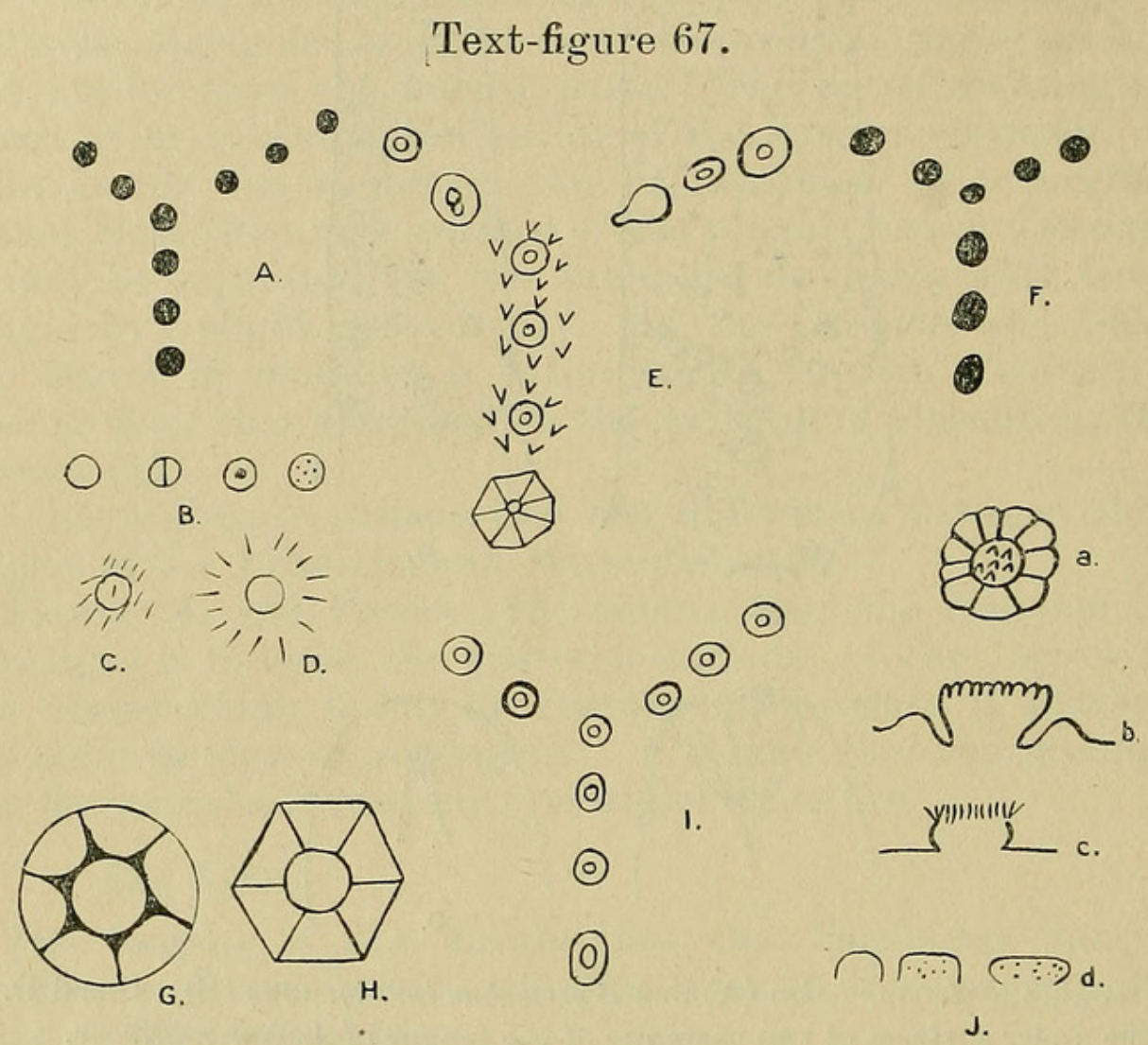

The vallate papillæ of the Lemuroidea: A-D. Lemur fulvus; E. L. rufifrons ; F-H. L. macaco; I. L. mongoz; Ja-Jc. plan and elevation of papillæ of L. rubriventer; Jd. fungiform papillæ of Lemur.

The conical papillæ (text-fig. $68 \mathrm{~A}$ ) have the usual arrangements in clusters and rows, and their points run in the usual directions. Those on the oral part of the dorsum are small, but those on the pharyngeal part are big and cylindrical or scale-like. These two groups are separated by a line of demarcation concave forwards, lying a little in front of the vallate papillary area. The points of the basal papillæ are straight or recurved. This arrangement is also present in Hapalemur, according to Beddard (1), and Chiromys, but is absent in Microcebus, the Lorisidæ, Galagidæ, and Tursius,

The lateral organs (text-fig. $68 \mathrm{~B}-\mathrm{E}$ ) consist of laminæ and sulci on the dorsum alone (L. macaco) or on the lateral borders and inferior surface. The central laminæ are larger than the lateral ones, and the inner border of each organ is convex towards 
the lateral vallate papillæ as in the Simiidæ. The relative position of these papillæ to the organs varies in different species, lying level with the central or posterior laminæ. In Microcebus the lateral organs are absent, and this condition, together with the number and arrangement of the vallate papillæ and state of the conical papillæ, links the tongue to those of the Lorisidæ and Galagidæ, and distinguishes it from those of Lemur. The numbers of laminæ and sulci frequently differ in the two organs of the same tongue, and the secondary sulci may be well marked or indistinct.

Text-figure 68.

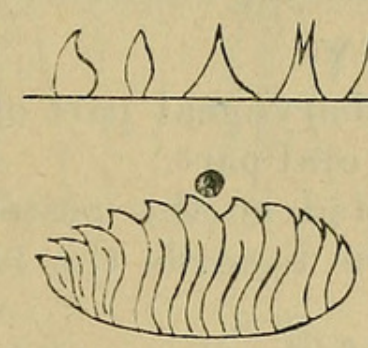

B.

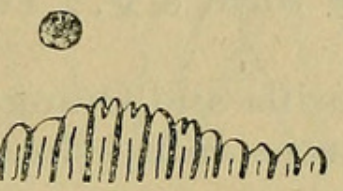

D.

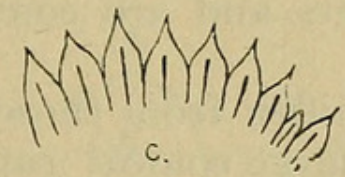

2.

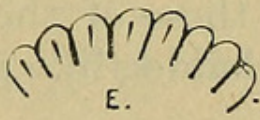

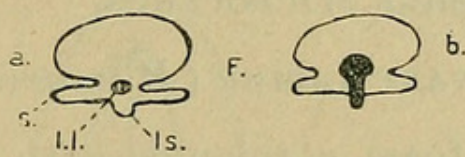

A. Conical papillæ of Lemur; B-E. lateral organs of L. catta (B), L. fulvus (C), L. macaco (D), L. mongoz (E) ; F. cross sections of the tongue of Chiromys in the anterior (a) and middle (b) thirds : (s. sublingua, 1.l. lytta of tongue, l.s. lytta of sublingua).

The ventral papillary zone is narrow and has many conical but few fungiform papillæ, and the ventral mesial sulcus may contain a mesial crest; it is absent altogether in some examples of each species, but present in others.

The sublingua (text-fig. 69) is triangular or lyrate, and the apex is divided into a small group of slender denticles. The edges are serrated in L.cattr, L. macaso, and L.varius, and entire in L. fulvus and L. fulvus rufifions. The median crest is well developed, but the lateral ventral crests vary in size. Between the base of the sublingua and the frenal lamellæ is a deep sulcus which is sometimes $\mathbf{V}$-shaped.

The frenum consists of two lax portions separated by the sublingua. The first extends fiom the floor of the mouth to the under surface of the sublingra, and the second runs from the upper surface of the sublingua to the mesial ventral sulcus of 
the tongue. The frenal lamellæ, which are sometimes complex, have the following characters:-

1. L. catta: lamellie are two blunt rounded processes.

2. L. coronatus : lamellæ form a parallel-sided flap.

3. L. macaco: triangular with rounded apex and lobulated sides.

4. L, varius: two broad flaps with rounded anterior borders and sharply cut mesial borders.

5. L. mongoz: lamellæ form a parallel-sided flap.

The tongues of the species of Lemur resemble those of the Chimpanzee and Gibbons in the following respects:-

1. Several vallate papillæ form a $\mathbf{Y}$.

2. The conical papillæ on the pharyngeal part of the tongue are much larger than those on the oral part.

3 . The lateral organs are situated at the posterior parts of the lateral borders and are convex towards the lateral vallate papillæ.

The tongues differ from those of the Orang-Outan and Man, which have no large conical papillæ on the pharyngeal part of the tonguie, and the vallate papillæ. form a V. These also have the Apical Gland of Nuhn.

They differ from those of the Gorilla and Orang-Outan, whose lateral organs form ladder-like patterns on the dorsum.

\section{Genus Microcebus. \\ Smith's Dwarf Lemur (M. murinus).}

Three vallate papillæ form a triangle with the base anterior ; the basal papillæ are small and circular, but the apical papilla is large, round, and granular.

The conical papillæ increase in size from the apex of the tongue to the epiglottis, and those on the base are not disproportionately large as in Lemur and Hapalemur.

Lateral organs are absent.

The sublingua is a flat horny plate with a row of denticles on its anterior border.

One can see, therefore, that there is no resemblance in any of the essential points between the tongues of Lemur and Microcebus, but the latter resemble those of some of the Lorises, Galagos, and Pottos, described below.

\section{Family I N D R I S I D E.}

\section{Genus Indris.}

Flower (4) described the tongue of 1 . brevicaudatus as follows:- "The tongue is long and narrow, with an obtuse point at the apex, being less truncated than in Lemur. It is 
$2 \frac{1}{2}$ inches long; and $\frac{7}{8}$ inch broad at its widest point. The dorsal surface is covered with a very close-set velvety pile of small papillæ, apparently all of one kind. There are two small circumvallate papillæ, $\frac{3}{10}$ inch apart, just in front of the attachments of the palato-glossal folds."

The sublinguæ resemble those of the Lemuridæ.

Text-figure 69.

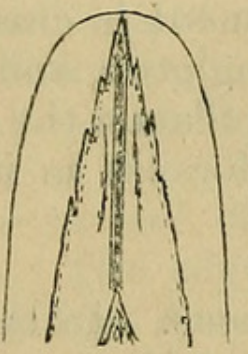

4 .

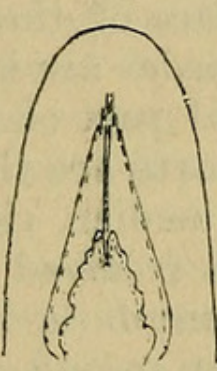

E.

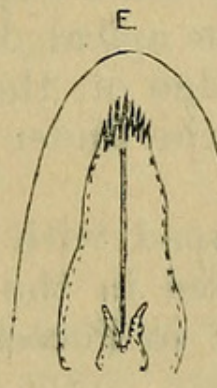

I.

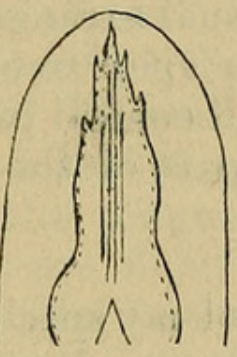

B

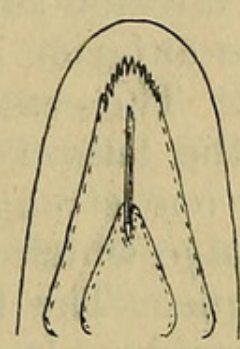

F.

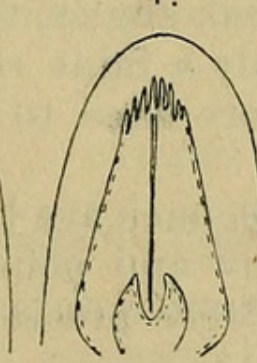

$\mathrm{J}$.

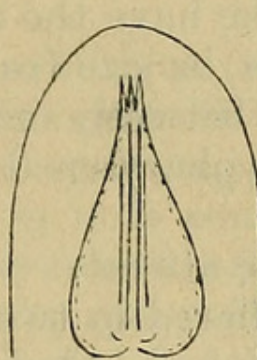

C.

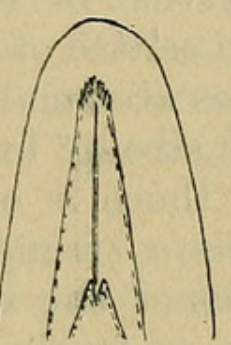

G.

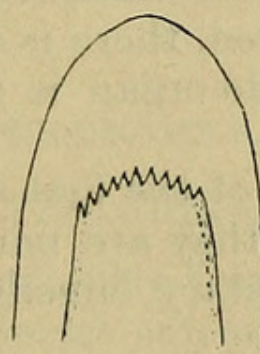

K.

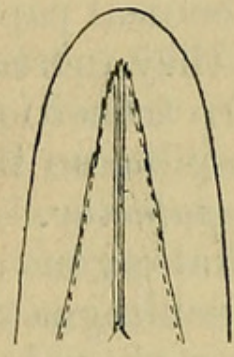

D.

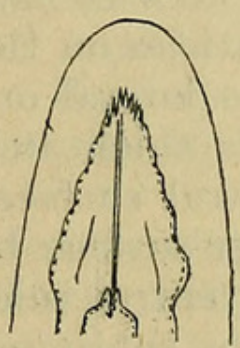

H.

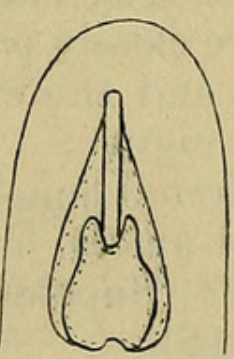

L.

The sublingua of Lemur catta (A.B), L. fulvus (C), L. rufifirons (D), L. macaco

(E); Nycticebus tardigradus (F.G); Loris gracilis (H); Perodicticus potto

(I); Hemigalago demidoffi (J); Galago crassicaudata (K); Tarsius spectrum (L).

\section{Family L O R IS I D..}

\section{Genus Nycticebus.}

The Slow Loris ( $N$. tardigradus).

Three preserved specimens were examined, and their lateral borders were seen to have no lateral organs. The apex, sulci, and bare area in front of the epiglottis were similar to those of Lemur.

Three vallate papillæ (text-fig. $66 \mathrm{~B}$ ) form an equilateral triangle with the base behind. All are circular, prominent, and 
finely granular; the fossæ are well marked and the vallums appear as clear zones. They are conical on elevation, the bases of the cones projecting beyond the fossæ. In two specimens the papillæ are of equal size, but in the third (Mus. R.C.S.) the apical papilla is smaller than the basal ones.

The fungiform papillæ are not numerous, and form a dorsal bounding zone on which they have the usual arrangement in rows and clusters, but the apical cluster is small ; and they are few in number on the ventral papillary zone.

The conical papillæ have the usual arrangement in clusters and rows; they increase in size from apex to epiglottis, and there is no sharp transition between small conical papillæ on the oral and large papillæ on the pharyngeal part of the dorsum as in Lemur and Hapalemur.

Lateral organs are absent.

The sublingua differed in two of my specimens. In the first it is tongue-shaped with a broad base whose angles are rounded, and its area is half that of the inferior surface of the tongue. The denticles on the centre of the anterior border are large, but the more lateral ones are smaller. The central part of the sublingua is thick and strong, but the lateral parts are thin. On the ventral surface there is only one strong median ridge, and the upper surface has a strong ridge which is received into the median ventral sulcus of the tongue. The frenum is long and lax, so the sublingua is freely movable. In my second specimen the sublingua has no rounded basal angles, the apical denticles are more closely packed, there is only a faint ridge on the upper surface, and the whole organ is more fixed to the under surface of the tongue.

The frenal lamellæ of the first specimen are broad, with bluntly rounder apices, but they are narrow and pointed in the second example. Supplementary lamellæ were present in Pocock's specimen (15).

The median ventral sulcus has no crest, but receives the ridge on the upper surface of the sublingua.

\section{Genus Loris.}

\section{The Slender Loris (Loris gracilis).}

The conical tongue narrows rapidly from base to apex, and its proportions are small.

Three va'late papillæ form an isosceles triangle with the apex behind. All are circular, furrowed, and granular, and are surrounded by prominent vallums. None are overlapped by conical papillæ.

The fungiform papillæ differ from those of Nycticebus tardigradus in that they extend right across the dorsum. They have the usual arrangement in rows and clusters, but the transverse 
rows extend far forwards at the expense of the apical cluster. Those at the posterior part of the oral division of the dorsum are large, hemispherical, polished, and close together. Few are present on the inferior surface of the tongue.

The conical papillæ resemble those of Nycticebus tardigradus in their mode of enlargement from before backwards, and differ from those of Lemur and Hapalemur. Most of the papillæ are cylindrical, and are surrounded by zones of interpapillary dorsum.

Lateral organs are absent.

The following account of the sublingua (text-fig. 69) is supplementary to those of Tiedemann (18), Otto, Vrolik (16), and Gegenbaur (5). It is leaf-shaped and wrapped round the convex inferior surface of the tongue, so it is concavo-convex on cross section. The edges are finely crenated and the apex is sharp. The denticles are smaller, less numerous, and more closely packed than those of Nycticebus tardigradus, but the characters of the central and lateral parts are similar in both cases. The mesial dorsal crest is not so pronounced as that of some examples of Nycticebus, but is equal to that of others. Both species have equally mobile sublinguæ, but the freedom is less than that of Lemur.

The frenal lamellæ are two small, rounded processes whose edges extend postero-laterally for a considerable distance. No accessory lamellæ are present.

The median ventral sulcus resembles that of Nycticebus tardigradus.

\section{Genus Perodicticus.}

Bosman's Potto (Perodicticus potto).

The tongue, which narrows slightly from base to apex, has no apical notch and no mesial dorsal sulcus, but possesses a few small, narrow transverse sulci in the posterior part of the oral division of the dorsum.

The circumvallate papillæ. - Van der Hoeven (6) described and figured three large papillæ in a triangle with the apex behind. In the specimen in the Museum of the Royal College of Surgeons there are three large excavated papillæ forming a triangle. In my specimen there are three in a triangle, but the apical papilla is divided into two large elongated parts enclosed in the one fossa.

The fungiform and conical papillæ do not differ materially from those of Nycticebus tardigradus.

Lateral organs are absent.

The sublingua is tongue-shaped and has nine apical denticles as in $P$. ibeanus. Its strong median ventral crest is bifurcated posteriorly, and the dorsal ridge is larger and sharper than that of any other species which I examined. The edges are devoid of 
serrations and the degree of mobility is equal to that which exists in Nycticebus and Loris (text-fig. 69).

Nussbaum (11) pointed out that the sublingua has a rod-like core, which he termed the "lyssa of the sublingua." It has a connective-tissue sheath and consists of fat, cartilage, and connective tissue. It is connected above to the lyssa of the tongue which contains fat, connective tissue, and muscle fibres.

The frenal lamellæ are two conical processes whose crenated edges extend postero-laterally almost as far as the palato-glossal folds.

The median ventral sulcus has no crest, but receives the prominent median dorsal ridge on the sublingua.

\section{Family GA L A GID Æ.}

\section{Genus Galago.}

The Bushy-tailed Galago (G. crassicaudata). Mus. R.C.S.

The tongue was preserved, so no measurements were made.

Three vallate papillæ are arranged in the form of an isosceles triangle with long sides. They are large, oval, and excavated, the fossæ are patulous, and the vallums appear as clear zones. The basal pair are opposite the attachments of the palato-glossal folds. Flower (4) also recorded three papillæ in the form of a triangle.

The fungiform papillæ are small, rounded, and arranged in the usual manner.

The conical papillæ increase in size from before-backwards, and there is no sharp line of contrast between those on the oral and those on the pharyngeal parts of the tongue as in Lemur and Hapalemur. Flower states that they are thick on the base of the tongue. They have denticulated points directed backwards.

The lateral organs are absent, the mesial ventral sulcus has no crest, and the ventral papillary zone has no fungiform papillæ.

The sublingua (text-fig. 69), which is flat, horny, and tongueshaped, has a rounded anterior border bearing sixteen squat sharp-pointed denticles. It covers rather more than half of the width of the under surface of the tongue and half of the length of the free part between the apex and frenum. The sides are parallel and entire. Flower's specimen had upturned edges and a downwardly-directed apex which adapted its form to that of the under surface of the tongue.

\section{Genus Hemigalago.}

\section{Demidoff's Hemigalago.(H. demidofi $)$.}

The small conical tongues of both my specimens have three vallate papillæ arranged in the form of a triangle with the apex 
directed backwards; the basal papillæ are small and circular, and the apical papilla is large, circular, and granular, with a patulous fossa.

The fungiform papillæ are not numerous, but stand up prominently. They have the usual arrangement, but the apical cluster is small. They form a well-marked row of closely-set elements on the posterior third of each lateral border of the tongue. None are present on the inferior surface of the tongue.

The conical papillæ give the surface of the tongue a finelygranular appearance. They increase in size from before backwards, and there is no sharp contrast between the papillæ on the oral and pharyngeal parts of the tongue as in Lemur and Hapalemur. When the tongue is dried they stand up prominently and reach a higher level than the summits of the fungiform papillæ. They form a narrow ventral papillary zone.

Lateral organs are absent.

The sublingua (text-fig. 69), which is flat, horny, and tongueshaped, has a rounded, denticulated, comb-like anterior border, and nearly parallel, entire edges. It has a well-marked median crest, but no lateral ridges, and it covers a larger area of the under surface of the tongue than that of the Galago.

The frenal lamellæ are small and pointed, and the mesial ventral sulcus does not contain a crest.

Pocock (15) described nine apical denticles on the sublingua of Galago monteiri.

Family CH I R O M Y I D

Genus Chiromys.

The Aye-Aye (C. madagascariensis).

The following description is supplementary to the existing accounts by Owen (13) and Peters (14) :-

Measurements. - Total length $4 \cdot 6 \mathrm{~cm}$.; oral part $3 \cdot 1 \mathrm{~cm}$; pharyngeal part $.5 \mathrm{~cm}$.; width between the lingual attachments of the palato-glossal folds $1 \cdot 6 \mathrm{~cm}$.

The apex is thick and rounded, but has no notch, and the massive lateral bordcrs are devoid of lateral organs. Mesial dorsal and mesial ventral sulci are absent.

Three circumvallate papillæ are arranged in the form of a triangle with the apex behind. All are circular and granular, and surrounded by nodulated vallums. Owen described two papillæ, about two lines apart, lying about an inch and a half behind the apex of the tongue. Peters recorded three papillæ arranged in a triangle, and figured nodulated vallums.

The fungiform papillæ are not numerous. They extend right across the dorsum, but are scanty in the middle line. They have the usual arrangement, but the apical dorsal cluster is small. One large papilla bisects the base of the vallate papillary triangle. 
None are present on the inferior surface of the tongue. They are smooth or granular, and are hemispherical or pedunculated.

The conical papillæ have the usual arrangement. They are closely packed and exhibit considerable mutual compression. Some are low and cylindrical, but others stand up prominently.

The papillæ on the oral part of the tongue are smaller than those on the base, and a line of demarcation, concave forwards, separates the two groups. The tongue resembles those of Lemur and Hapalemur in this respect, and differs from those of the Lorises, Pottos, and Galagos. There is also an area devoid of papillæ in front of the epiglottis ; this is bisected by the median glosso-epiglottic fold.

The sublingua has been described by Owen (13), Gegenbaur (5), and Pocock (15), but several details are omitted, or not sufficiently emphasised, in their accounts.

It is a flat horny plate with entire lateral margins and a rounded anterior border with a central projection, whose point marks the place where the strong, denticulated median ventral ridge bends downwards in a hook. This crest increases in depth from behind-forwards, and its hook lies $9 \mathrm{~mm}$. posterior to the apex of the tongue.

It was shown in the descriptions of the sublingure of the Lorises that there is a thick central strip and two thin lateral parts. The same parts are present in Chiromys, but differ from those of the Lorises in that the central part is adherent to the under surface of the tongue, but the lateral parts are free; in the Lorises, on the other hand, both parts are free. Gegenbaur and Pocock both describe a free lateral margin, but do not give any idea of the extent of the free part. In my specimen the total width of the sublingua is $1.2 \mathrm{~cm}$; the central firm adherent part is $\cdot 6 \mathrm{~cm}$. wide, and each free lateral part is $\cdot 3 \mathrm{~cm}$. wide. A probe can be passed for a considerable distance between the under surface of the tongue and the sublingua. No denticles project from the anterior border.

Pocock (15) described the two small glandular (?) pockets on each side of the frenum, and pointed out that the frenal lamellæ are narrow.

Gegenbaur (5) described the horny nature of the sublingua, but did not show how the thickness varies in different parts. Although one thinks that the central parts are thicker than the lateral parts, when the tongue is entire, one sees that the reverse is the case when sections are made. The apparent thickness of the central part is due to a downward projection of the lingual muscles to which the central part of the sublingua is closely applied (text-fig. $68 \mathrm{~F}$ ).

The Lytta - The tongue possesses a strong median ridge on the under surface of the sublingua, which Owen termed the "lytta." He did not describe sections of the tongue, for a welldeveloped lytta is present close to the sublingua. Gegenbaur made the same omission, but Nussbaum (11) recorded its 
presence. It is united to the upper surface of the sublingua in the median part of the latter. 'The condition resembles that of Perodicticus, in which there are lingual and sublingual lyttæ. In the latter species both lyttæare internal. The position of the lytta in different parts of the tongue is seen in text-fig. $68 \mathrm{~F}$.

\section{Family TARSIID E.}

\section{Genus Tarsius.}

\section{The Tarsier ( $T$. spectrum).}

The classical work of Burmeister (2) and the subsequent papers by Gegenbaur (5) and Pocock (15) have dealt with most points, so the work of any observer is now comparatively limited.

In the specimen in the Museum of the Royal College of Surgeons the shape of the tongue and the characters of the vallate, fungiform, and conical papillæ are similar to those described by Burmeister. That author does not mention that the lateral organs are absent. There is no great contrast between the conical papillæ on the oral part of the tongue and those on the base.

The sublingua is soft and defined from the under surface of the tongue by a groove only; it is the most adherent sublingua among the Prosimix. The median ventral rod does not terminate in a knob as in Pocock's specimen, but its free anterior extremity is rounded (text-fig. 69), and is slightly turned downwards as in Chiromys; as the specimen was preserved, I am unable to say whether this curving of the ridge was produced by the alcohol.

The frenal lamellæ are two conical tapering processes, and differ from the conditions recorded by Burmeister and Pocock.

\section{Summary and Conchusions.}

1. The tongues of the species of Lemur resemble those of the Chimpanzee and Gibbons in the $\mathbf{Y}$-formation of their vallate papillæ, their convex lateral organs, and the contrast between the large conical papille on the pharyngeal part of the tongue and small ones on the oral part. They differ from the tongues of Man and the Orang-Outan in that the latter have no large conical papilla on the base of the tongue, and their vallate papillæ form a V. They differ from the tongues of the Gorilla and Orang-Outan, whose lateral organs form ladder-like patterns on the dorsum of the tongue.

2. The tongue of Microcebus differs in the essential features from those of the species of Lemur, and resembles those of the Lorises, Galagos, and Pottos.

3. The tongues of the Lorisidæ and Galagidæ differ from those of Lemur in so many features that they are important fore purposes of classification. Adding them to other characters 
described by Pocock, Forsyth Major, and others, we obtain the following comparison :-

\section{Lemur.}

1. Vallate papillie form a $\mathbf{Y}$.

2. Lateral organs convex.

3. Conical papillæ small on the oral part of the tongue and large on the base.

4. Sublingua triangular or lyrate, with apical denticles.

5. Urethra opens above tip of clitoris.

6. Ectotympanic annular or horseshoe-shaped and inside bulla.
Lorisida and Galagida.

1. Vallate papilla form a triangle.

2. Lateral organs absent.

3. Conical papillæ increase gradually from the apex of the tongue to the epiglottis.

4. Sublingua tongue-shaped, with denticles along its anterior border.

5. Clitoris traversed by urethra.

6. Ectotympanic external to bulla, of which it forms the outer wall.

I have not had the opportunity of examining the tongues of the Indrisidx, but published accounts and illustrations ally them to those of Lemur.

4. The tongue of Chiromys has its own characteristic sublingua, which has a larger area free from the tongue than existing accounts lead one to expect. It has no lateral organs, but its basal conical papillæ are large. It has two or three vallate papillæ. Its characters resemble those of Lemur on the one hand and those of the Lorisidæ and Galagidæ on the other.

5. The tongue of Tarsius spectrum has the most adherent sublingua. It stands by itself in the consistence and size of the sublingua and the characters of its vallate papillæ.

6 . The frenal lamellæ are frequently very complex, and supplementary lameslæ are present in Nycticebus tardigradus.

7. The foramen cæcum and Apical Gland of Nuhn are absent.

8. The lytta is present in several forms, and is frequently accompanied by a central axis, or lytta, of the sublingua. In the other Primates this is absent.

\section{Bibliography.}

1. Beddard, F. E.- " On some Points in the Structure of Hapalemur griseus." P. Z.S. 1884, p. 391.

2. Burmeister, H.- "Beiträge zur näheren Kenntnis der Gattung Tarsius." Berlin, 1846.

3. Campen, F. A. W. van.--Verhand. der König. Akad. van Wetenschappen, Amsterdam, 1859.

4. Flower, W. H.- "Lectures on the Anatomy of the Organs of Digestion of the Mammalia." Med. Times and Gazette, 1872. 
5. Gegenbaur, C._- "Über die Unterzunge des Menschen und der Säugethiere." Morph. Jahrb. 1884, p. 428.

6. Hoeven, J. van der.- "Bijdrage tot de Kenntnis van den Potto van Bosman." Amsterdam, 1851.

7. Huxlex, T. H._- "On the Angwántibo (Arctocebus calabarensis)." Proc. Zool. Soc. 1864, p. 314.

8. Kingma, P. H._" Eenige Vergelijkend-Ontleedkundige Aanteekeningen over den Otolicnus Peli." Leyden, 1855.

9. Meckel, J. F.-System der vergleichenden Anatomie. Teil 4. Halle, 1829.

10. Müхch, F._- Die Topographie der Papillen der Zunge des Menschen und der Säugethiere." Morphol. Arb. 1896.

11. Nussbaum, J.-Anat. Anz. pp. 551-561, 1896 ; and pp. 345$358,1897$.

12. Oppel, A.-Lehrb. der vergl. mikr. Anat. vol. iii. pp. 251270 and $391-393$.

13. Owen, R.- "Monograph on the Aye-Aye." Trans. Zool. Soc. London, vol. v. p. 33, 1863.

14. Peters, W. — UÜber die Säugethiergattung Chiromys." Abh. der Königl. Akad. der W iss. zu Berlin, 1865.

15. Pocock, R. I. " On the External Characters of the Lemurs and of Tarsius." P.Z.S. 1918, pp. 19-53.

16. Schreder, J. L. C., VAN der KoLK, and W. VROLIK.Bijdragen tot de Dierkunde, uitgegeven door het Koninklijk Zoologisch Genootschap "Natura Artis Magistra." Eerste Deel. Amsterdam, 1848-54.

17. Sonntag, C. F.-Papers on the Tongues of the Primates. P. Z.S. 1921, pp. 1-29, 277-322, 497-524.

18. 'Tredemanx, E.-Arch.f. Anat. u. Physiol. vol. v. pp. 348-356, 1819.

19. Tuckermax, F.-Journal of Morphology, vol. vii. pp. 69-94, 1891.

20. Sonntag, C. F.-P. Z.S. 1921, pp. 547-577. 


\section{$2 \mathrm{BHL}$ Biodiversity Heritage Library}

Sonntag, Charles F. 1921. "38. The Comparative Anatomy of the Tongues of the Mammalia. - V. Lemuroidea and Tarsioidea." Proceedings of the Zoological Society of London 1921, 741-755.

https://doi.org/10.1111/j.1096-3642.1921.tb03289.x.

View This Item Online: $\underline{\text { https://www.biodiversitylibrary.org/item/97766 }}$

DOI: https://doi.org/10.1111/j.1096-3642.1921.tb03289.x

Permalink: https://www.biodiversitylibrary.org/partpdf/72104

\section{Holding Institution}

Smithsonian Libraries

\section{Sponsored by}

Biodiversity Heritage Library

\section{Copyright \& Reuse}

Copyright Status: Public domain. The BHL considers that this work is no longer under copyright protection.

This document was created from content at the Biodiversity Heritage Library, the world's largest open access digital library for biodiversity literature and archives. Visit BHL at https://www.biodiversitylibrary.org. 